\title{
ATLANTIS IN SPAIN
}

\section{Papamarinopoulos S.P.}

University of Patras, Department of Geology, Patra, Greece

\section{Part IV: The concentric city and its geological significance}

\begin{abstract}
Many analyst in the past faced Atlantis' main city with the same way they faced his idealised concentric cities which he described in his dialogues. However, Atlantis' concentric city has a marked difference which is recognisable if the analyst has geological knowledge. For instance the concentric scheme, the geothermal springs and the black, white and red rocks correspond in volcanogenic, impactogenic and diapeirogenic craters. It is known that building material from rocks existing in the vicinity of the two first, from the three, types of craters have been used in the past. It is also known that cities have been developed both on volcanogenic craters such as Santorin in the Aegean Sea, or on impactogenic craters such as in Nordlichen in Germany and in Yemen's capitol respectively. A simulation experiment was carried out exactly in the platonic geomorphological conditions assuming that the concentric scheme could be of impactogenic origin. The result showed that such multi-ringed crater exhibits the platonic characteristics presented in Critias. However, such solution is not unique because the other two types of craters have not been tested yet. The statistical criterion which may be applied in all three simulations in the described platonic environment will decide by itself which is the most optimal solution between all three. Many experts who know nothing about Plato's views about science and mythology can not differentiate between genuine and fabricated myths utilised by Plato. Most of them do not understand that the multiringed crater called Atlantis too by Plato is revealed in the ancient myths prior to Plato and was placed by these writers West of the Gibraltar Straits. Philostratus, in Roman times, is the only Greek writer who described its geological nature in detail and presented its position in Southern Spain. That crater Geryonis was associated with Heracles' visit in Iberia. In the latter's sea environment there are several submerged gigantic diapeirogenic craters and a small one visible even today in Andalucía's. The geological age of the submerged craters, in Cadiz, precedes the prehistoric Greeks' and Iberians'presence in the area. One of them possibly became the object of observations of prehistoric Greek mariners who passed Heracles' Pillars and it was interpreted as Poseidon's act. These Greek mariners were accustomed to interpret craters in the Aegean Sea such the Nisyros', for instance, one as Poseidon's act too.
\end{abstract}

\section{Introduction}

Plato in the Laws presented an idealized concentric city shown in Fig. 1. In that city he incorporated his town planning, political, philosophical and mathematical ideas which became known from multiple scientific studies. However, at Critias, Plato presented another concentric city-port with equal and exceptional town planning details. It has been recognized, long time ago, that this particular city associated with the Atlantes' culture had certain distinct geological properties implying a nature born initial structure like a volcanogenic, impactogenic or diapeirogenic crater. On it the Atlantean prehistoric city had been built. Since the experts of the past had "established" that no other ancient author earlier or con- 


\section{Fabricated and non-fabricated myth}
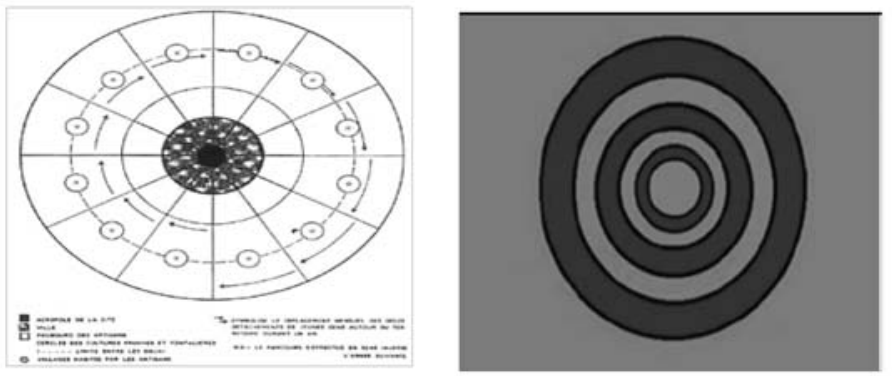

Fig. 1: An idealized concentric city presented by Plato in his dialogue the Laws. It has not any geological significance and consequently it is not an object for further analysis from the standpoint of natural sciences. However, the right picture which is Atlantis' general concentric scheme contains recognizable geological information.
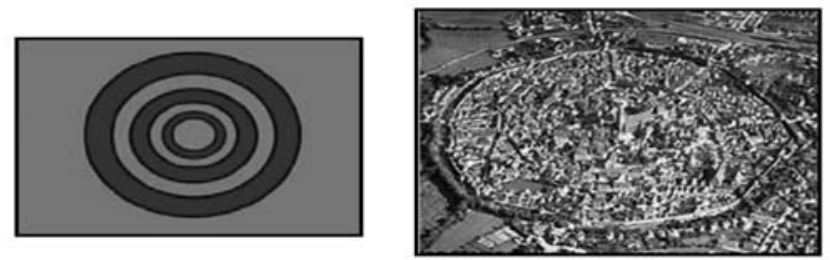

Fig. 2: The platonic concentric scheme versus the Nordlichen medieval city built upon an impactogenic crater.

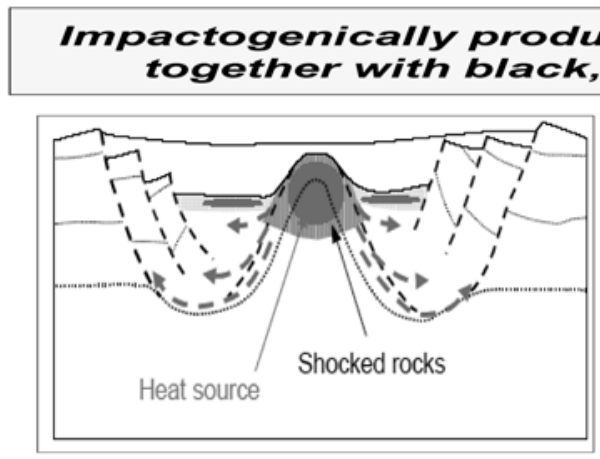

\section{geothermal springs}
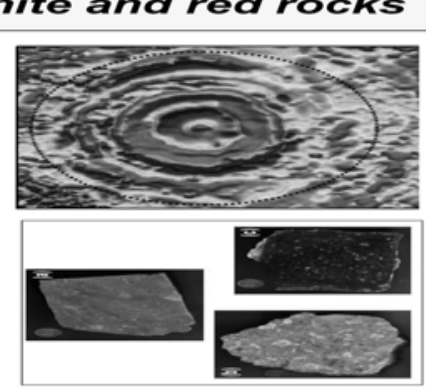

Fig. 3: A schematic presentation of a geothermal field produced by an impactor together with a geophysical image of a concentric scheme of a buried impactor. Black, white and red stones from Rochechouart's impactor in France.
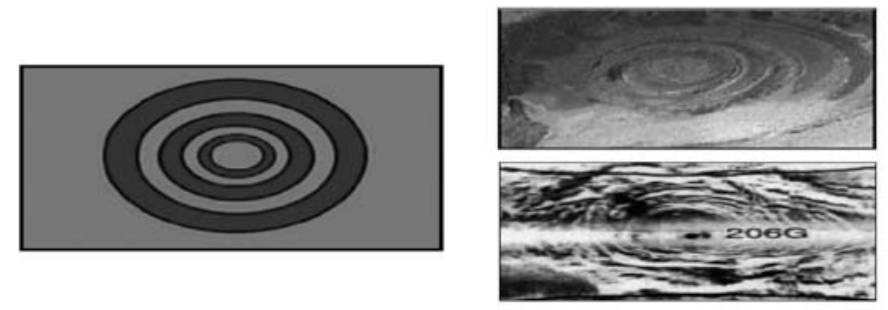

Fig. 4: The platonic concentric scheme and two diapeirogenic concentric (top Richat, Matton et al, 2005) and (bottom Cadiz, after Resbergen et al. 2005). 


\section{Predicted regime of temperature and pressure in Atlantis' environment}
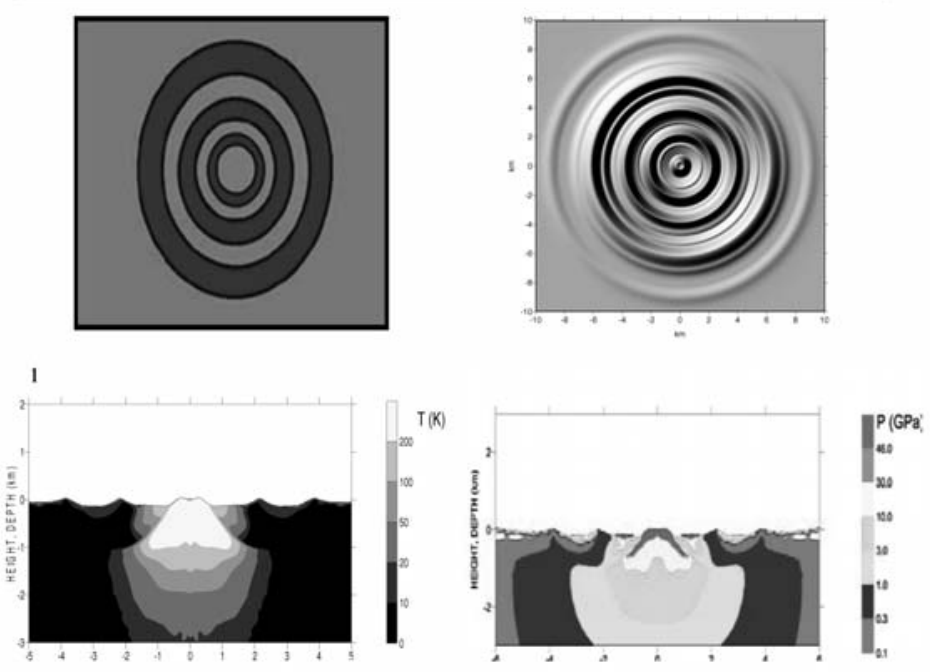

Fig. 5: The result of the arithmetic simulation is to the right of the platonic multi-ringed system. The regimes, produced by a buried impactor, of the temperature and the pressure are below of the two concentric schemes, (after Tsikalas et al, 2007a and 2007b). A similar simulation study should be carried out with a diapeirogenic crater.

temporary to Plato mentioned anything about that Atlantean culture and since it was known that Plato had lack of interest about history and moreover he had used many fabricated myths in his dialogues the case was clear for them that Atlantis was a petty fabricated platonic paramyth with no interest to science. We have demonstrated already (Papamarinopoulos, 2010c) that Plato's common use Atlantis' word, which he invented, for three different geological and geographic entities the giant island, the horseshow basin and the concentric scheme produced unwanted confusion. Figure 2 shows Atlantis' general concentric scheme together with Nordlichen the medieval German city which was built upon the impactogenic crater and whose buildings were constructed from impactites. Figure 3 shows a geophysical concentric image produced from a prospected buried impactogenic concentric crater together with the impactogenic regime of geothermal waters and the presence of black, white and red rocks collected from Rochechouart's crater in France. Red suievite prevails in Rochechouart. The impactogenic rocks were used by the Romans to built baths taking energy from warm impactogenic springs which were functioning for thousands of years after the impact.

\section{Ancient Greek Sources about Atlantis prior to Plato}

We will commence our study with Paul Jordan (2001) who refers to Hellanicus, a $5^{\text {th }}$ century B.C. writer, and interprets the few survived excerpts from his texts in an unscientific way. According to him, Hellanicus who lived some decades prior to Plato did not mention anything about Plato's Atlantis in his lost book. Jordan (2001) believes that Hellanicus described briefly Atlas' daughters, the so called Atlantides. Let us see the text.

Fragmenta 1a,4,F.19a.15 
... another one, called Kelaino, whose name means "who is dark in appearance" or darkish in the skin mates with Poseidon and their erotic offspring, Lykos, comes to life. Poseidon places him in the blessed islands where he becomes immortal.

Fragmenta 1a,4,F.19b.4

Luce (1978) was the first to find Hellanicus' particular phrase presented below to have an exceptional similarity to Plato's phrase. Both of them are presented in italics, firstly that of Hellanicus' and secondly then Plato's.

Fragmenta 1a,4,F.19b.4 - 1a,4,F.19b.6

"Poseidon mated with Kelaeno and their son Lykos was settled by his father in the isles of the blest in order to become immortal".

Plato wrote in Critias something similar to this.

Criti 113.d.4-113.d.5

"and Poseidon, being smitten with desire for her, wedded her".

We observe that Poseidon and Kelaeno in pre-patonic tradition illustrate an Earth's circularity symbolically in the Atlantic Ocean and then in the platonic tradition Poseidon and Cleito present symbolically the same circularity in the Atlantic Ocean. Hellanicus does not locate however its position.

We note that Plato immediately after this phrase describes the elaborated building of Atlantis by Poseidon. At this point Plato starts building his paramyth with his mathematical fantasies, (Brumbaugh, 1954).

According to Hellanicus, Poseidon had intercourse with a woman who is either dark in appearance or her skin is of a darkish type. Then he places the offspring of their love affair in the islands of the blessed. The islands of the blessed are most likely West of Gibraltar, as most ancient Greek authors suggest. According to Plato's version, Poseidon has intercourse with Cleito. One of his descendants is called Azaes whose skin is darkish so to speak. Gill (1980) interprets Azaes as a parched,dark-skinned person. The reader can now see the double similarity between the two passages. Jordan (2001) missed the point entirely because he saw in that only the Atlantide Kelaeno as a star in the constellation of the Pleiades.

Then in accordance with Plato, Poseidon also builds his palace West of Gibraltar. The common elements between the two versions are the erotic act which produces a "circle" in the woman's body implying the Earth. The darkish skin in both stories is very relevant in that Eurafrican part of the world. In other words, a nature made circularity in the Earth situated somewhere West of Gibraltar interpreted by the prehistoric Greeks as Poseidon's act became the kernel of the Atlantis case. Unfortunately Hellanicus' entire book, Atlantias, is missing and only some fragments have survived. Let us now consider what Pindar wrote who lived some decades before Plato too. Pindar describes another sacred wedding. "Somebody", whose name is missing, marries a woman, a Nereid, related to the sea as islander women in Plato's and Hellanicus' cases related in their respective stories.

Pindar says:

\section{N 4.65-4.70}

"He married one of the lofty-throned Nereids. He beheld the line circle of seats on which the lords of the sky and sea sat and revealed to him their gifts and his race's power. That which lies to the west of Gadeira cannot be crossed; Turn back again the ship's tackle to the mainland of Europe."

The poet describes a circular base where kings of sea and heaven were offering gifts to visitors and 

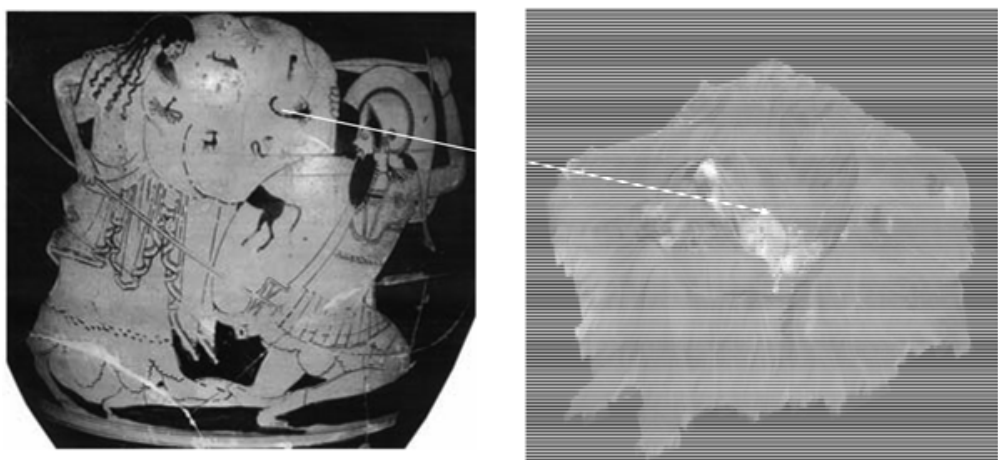

Fig. 6: Poseidon (left) fights with Polyvotis (right). Poseidon had just grabbed a piece of rock from Kos Island and he is ready to drop it against his enemy. A huge rock has already fallen upon Polyvotis and created Nisyros' crater in other words an Aegean circularity similar in shape to an Atlantic Ocean circularity in the eyes of the prehistoric Greeks.

speaking to them about their riches. Pindar in the following phrase defines the region of this rich race of kings. It is somewhere round Gadeira.

Let us come now to the $7^{\text {th }}$ century B.C. and examine Hesiod's texts.

Fragmenta 372.10-372.11

Hesiod describes what Poseidon's son, Chryssaor, achieved mimicking his father.

Th $287-290$

"But Chryssaor was joined in love to Callirrhoe, the daughter of the glorious Ocean, and begot threeheaded Geryones. Him mighty Heracles slew in sea-girt Erytheia."

Poseidon's son, Chryssaor, had an intercourse with the Ocean's daughter Callirrhoe on the land of Erytheia and gave birth to Geryones. Before attempting to interpret what Geryones could be, let us remind the reader that what Hesiod writes is very similar to what Plato describes. Poseidon in Plato's version is replaced by Chryssaor that is Poseidon's son, in Hesiod's version. They both do the same act as Hellanicus and Pindar describe. It is an erotic act at Erytheia somewhere West of Gibraltar. The latter is defined geographically by Stesichoros of the $7^{\text {th }}$ century B.C. to be close to Gadeira. But it is time to leave Hesiod temporarily and show the reader what the impression of the Greeks about Poseidon's act was in producing circularities in the Aegean Sea. In Fig.6 Poseidon fights against a warrior Polybotis, whose name means "many bulls". Polyvotis' name reminds us of Geryones' association with bulls in Erytheia region somewhere West of Gibraltar. Poseidon hits firstly Polyvotis with his trident and then drops a huge rock at him. The result of this action is a circularity in the island of Nisyros which is the volcanic crater under which Polyvotis is buried. In other words, he resembles the circularity. Is it possible that Geryones could be something like that?

Polyvotis and Geryones remain buried in the Aegean Sea and the Atlantic Ocean respectively. Poseidon is responsible as a warrior and/or a lover respectively. The latter symbolism was Achaeans' common understanding of large circular holes irrespective of the real producing mechanism in our modern science.

Let us come back now to the environment West of Gibraltar and follow what Poseidon himself normally does, apart from producing earthquakes and inducing floods.

Hesiod writes about him: 
Th 726-726

"round it runs a fence of bronze"

This "circular fence of bronze" is a characteristic example of Poseidon's building activity which builds round a crater. Furthermore Poseidon does again something similar as Hesiod writes:

Th $732-733$

"for Poseidon fixed gates of bronze upon it and a wall runs all round it on every side."

As the reader observes, Hesiod keeps insisting on describing Poseidon's capacity that is to build circular walls round Earth's craters.

However, Geryones', geological nature is mentioned by Philostratus a writer of $1^{\text {st }}$ century A.D. in his text VA5.4.9-VA5.5.9 in that he says the following among other information in connection with Gadeira and Geryones. Philostratus describes South-west Europe and North-west Africa too.

"They also say that the Islands of the Blessed lie at the extremity of Africa, rising near the deserted promontory."

"They claim to have seen trees there a kind that exists nowhere else on earth, and are called Geryones' trees. They are two in number, and grow from the grave that holds Geryones. Each combines the natures of a pine and a fir and drips blood, as we are told the Heliad poplar drips gold. The island on which the sanctuary stands is as large as the temple itself, and is in no way like a rock, but resembles a polished platform."

Philostratus described a specific tree characterised by the author as a pine tree uniquely existing in the region which weeps over Geryones' tomb shedding red tears. This tree is unique from of an observer's standpoint coming from the Mediterranean Sea. It is located at Erytheia West of Gibraltar, a region near Gadeira. This tree does not grow within the Mediterranean and consequently it was unique for prehistoric Greeks. It is called a Dragon tree and produces red resin! This is the source of the blood which the legend describes. The legend connects these trees with Geryones because two of them grew on the top of his tomb. Philostratus further describes the environment as an island saying that the areas of the island and the temple were the same. He also explains that Geryones' tomb had a top where a certain valvis, resembling a polished platform, existed. Since Erytheia is a land resembling a tomb with a circular flat top, then it is likely to be elevated. Its polished platform valvis is always in ancient Greece a point, a line or circle imposing limits on the ground. It has been used by the athletes. A circular valvis can be imagined if the reader bears in mind how and where modern athletes throw the discus. Erytheia's geomorphology, its likely elevated topography, and its flatness implying circular limits reflect an environmental tomb and a temple simultaneously. In other words the flat environment described by Philostratus looks likes a circular perivolos, as Achaean tombs normally exhibit. The gently hilly like structure of Erytheia's island could not have been considered as a tomb by the ancient Greek observers, if it had not been slightly elevated having a flat top. Thanks to Philostratus we understand that the initial observers interpreted an earthly natural phenomenon as a shouting giant. The reason was that they saw it as a circular mouth giving the impression of somebody shouting. We say shouting, since Geryones' name itself means shouting. In Figure 7 we show to the reader, in a sideways view, a small flat topped Geryones in Andalusia's red soil in other words in the legendary Eryhtheia's (red land) environment. In the same Fig.7 we show a set of submerged giant type of Geryones' structures. Some of them are concentric. They are all in the bottom of Cadiz's sea. 


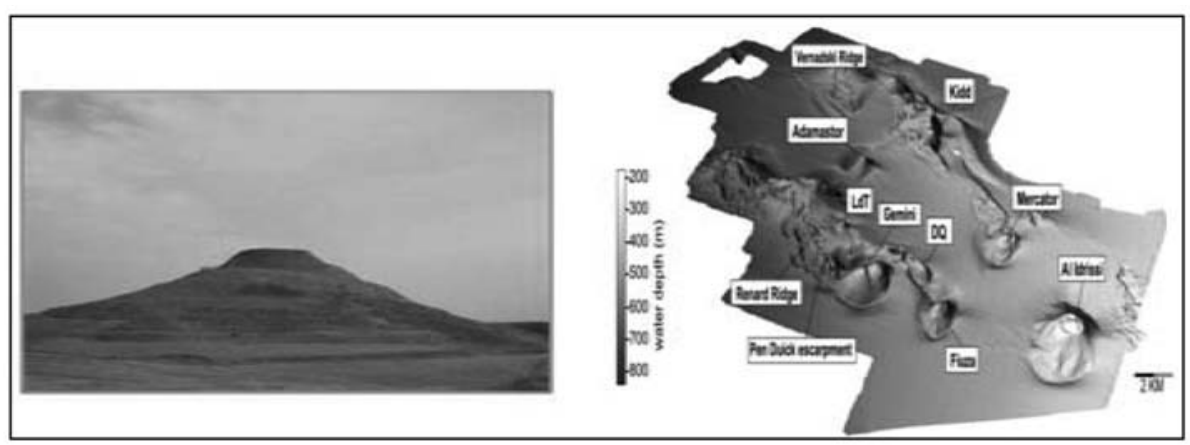

Fig. 7: A diapeirogenic Geryones from Spain in Andalusia with a flat valvis on its top to as Philostratus described it 2000 years ago. It could be interpreted as a tomb by Greek visiting prehistoric mariners because it looked like Mycenaean (Achaean) type of tomb, (Photo after Montexano). There are several submerged giant diapeirogenic craters in Cadiz's bay too. Some of them are concentric (map after Resbergen et al, 2005).
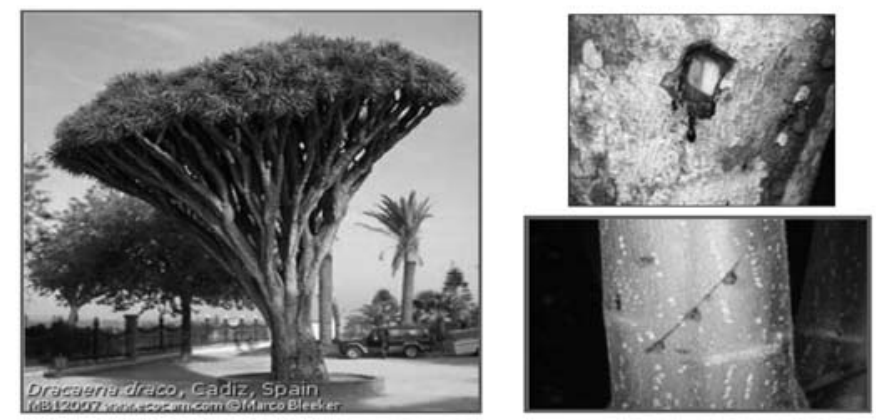

Fig. 8: A Dragon Dracaena tree in the Medical school Cadiz (left) is shown. Red resin from a Dragon Dracena and red tears from a tree's trunk, $(\mathrm{Pa}$ pamarinopoulos et al, 2007).

This diapeirogenic crater, shown in Fig.7 resembled what Philostratus described 2000 years ago. It has a flat, circular valvis on the top. But how can one interpret Geryones' three heads? The only way to interpret this, as an earthly natural phenomenon, is to imagine three heads one within the other. In other words the shouting Geryones exhibited a concentric three-ringed circular crater with a central flat surface on it. It is located somewhere in Erytheia (the red land) close to Gadeira. In that region (Gadeira), thanks to the Atlantic Ocean's climate, there appears the first sign of Dragon's Dracena tree with its westward unique distribution.

Today's observer can find a Dragon tree at Gibraltar and at Cadiz's Medical School along the coast of West Africa, in the Canaries in the Atlantic Ocean and elsewhere, but not within the Mediterranean Sea. It was and continues to be, a characteristic unique tree of the Atlantic Ocean. Figure 8 and illustrate a Dragon tree at Cadiz, red resin and red tears of a weeping Dragon tree.

The Atlantic Ocean Dragon tree is at first a short tree and then it grows very slowly. However, it can reach heights up to $19 \mathrm{~m}$. It looks like a giant holding the sky with his arms extended upwards.

But can we know anything more about Erytheia? Was it an island or an Iberia's extended land and where was it located exactly? The answer is partly positive. In order to extract some information about it, we have to study Steisichoros' $7^{\text {th }}$ century B.C. fragmented passages carefully and in detail. Let us read the first.

Fragmenta7.1-7.3 

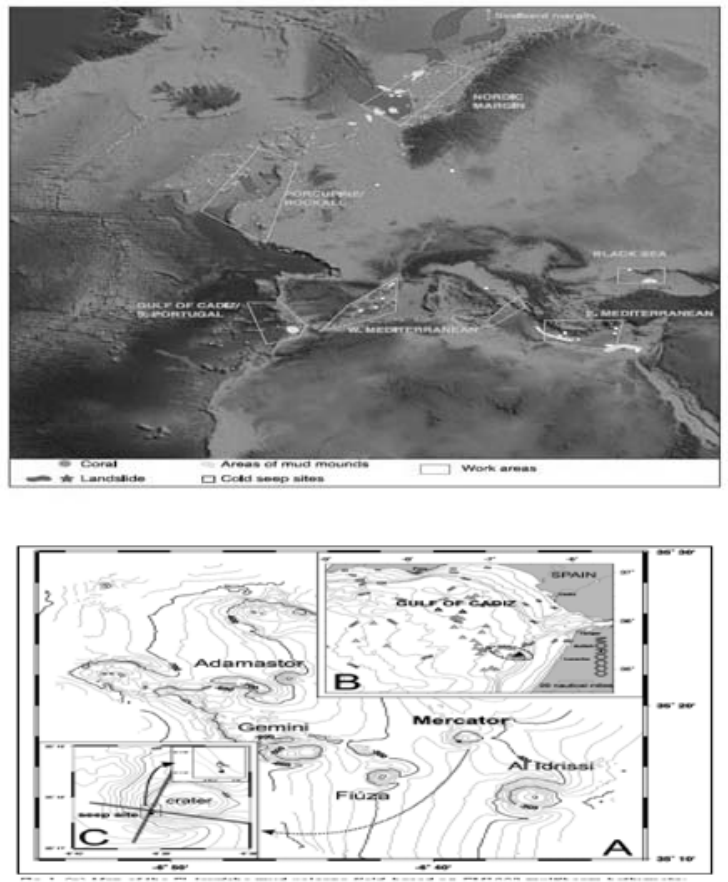

Fig. 9: Giant landslides and diapeirogenic craters (lighter colour perigrammes, dots and letters), (after Rooii, 2005).

Fig. 10: Giant diapeirogenic craters at Cadiz's bottom in a bathymetric presentation, (after Weaver, 2005).

"Almost opposite famous Erytheia... by the limitless silver-rooted waters of the river Tartessus in the hollow of a rock."

Stesichoros describes Erytheia's land as lying opposite a land where the Tartessos River exists close to some void associated with silver mines. It is the first time that a river delta is mentioned to be located in the land opposite Erytheia's land which is Andalusia of course. Bur a river delta is mentioned by Plato in his Atlantis. The river or channel intersected the concentric multi-ringed scheme.

But this Tartessos River was also Guadalquivir's River older name in southern Spain. The Greeks called Tartessos the Iberian city as well. In other words Andalusia's region is unavoidably described. Steisichoros, however, refers to Geryones too in another excerpt as follows:

Fragmenta S20, col1.2-S20,col2.3 tit102-103

From this particular fragment and from Hesiod's description we deduce that Geryones was on Erytheia's land and additionally that it was located between Gadeira and Iberia! But are we certain that Erytheia was an island with today's meaning or an extend land of Andalusia's basin? The answer is not positive. Erytheia is a word, appearing in the $7^{\text {th }}$ century B.C. In the latter century the concepts of peninsula and island had not been differentiated yet. Eryhteia can not be seen today due to a possible land slide occurred in Andalusia's coast. Erytheia's complexity requires another brilliant study similar to that which Chalari et al, 2010 conducted in Alexandreia. In that, Athena Chalari, demonstrated that in prehistoric times Pharos Island was a peninsula! Figure 9 illustrates a map of the distribution of past landslides and diapeirogenic (mud) craters in the Atlantic Ocean (Van Rooij, 2005). As the reader can see the marks of mud craters exist in detail right in the bay of Cadiz (Weaver, 2005). They are shown in Fig.10. The landslide regions are close and within the light colour perigrammes which show dots and letters of diapeirogenic craters.

Since no words of differentiated meanings of islands and peninsula existed before the $5^{\text {th }}$ century B.C. 
since Herodotus added for first time the word peninsula in alphabetic Greek, we can deduce that either geological reality could be meaningful. However, it is important to know at some stage in Cadiz's bay and in Andalusia's coast the dates of any possible landslides and the scenario under which they were formed.

But in another fragment Stesichoros continues and states the following:

Fragmenta S20,col2.1-col2.6

"...over the waves of the deep brine they came to the beautiful island of the gods, where the Hesperides have their homes of solid gold;...(buds)".

Stesichoros describes the wonderful island and relates the Hesperides (Pleiades) to it. But the surprise is the case of the Hesperides mentioned again two centuries before Hellanicus' period. In Hellanicus $5^{\text {th }}$ century B.C. Poseidon mates with Kelaeno (one of the Hesperides) and their offspring is placed on the islands of the blessed somewhere West of Gibraltar. In the legend of the Hesperides, also called Atlandites, there is an obvious astronomical layer apart from the earthly. The first does not contradict the second. The astronomical layer reflects knowledge of Pleiades' constellation associated possibly with calendrical systems used my mariners. But the case of Hesperid Kelaeno illustrates another earthly layer as a piece of additional information in connection with a particular region West of Gibraltar. This information is the Poseidon's erotic act on Earth as it was conceived by the Greeks somewhere West of Gibraltar. Versions of the Earth having a circular chasm in a marine environment are Calirrhoe in Hesiod, Nereid in Pindar, and Cleito in Plato. These ladies, representing Earth, had an erotic contact with Poseidon in an exotic for the prehistoric Greeks environment. The various versions of the legend are multiples attempts of the prehistoric Greeks in the region of Gadeira-Andalousia to interpret a particular circular chasm, once visible. Any of these circular chasms become once a sacred and religious center of Iberians long before the advent of Phoenicians.

But let us go deeper in time and reach Homer's period. Do we have a symbolic presentation of a circularity anywhere? The answer is positive. Let us study the following passages one after the other.

Od13.146-13.152

"Then Poseidon the earth-shaker, answered him:

Quickly should I have close as you say, god of the dark clouds, but always I dread and avoid your wrath. But now I am minded to smite the beautiful ship of the Phaeacians, as she comes back from her convoy on the misty deep, that hereafter they may desist and cease from giving conveyance to men, and to hide their city behind a huge encircling mountain".

In the text above Poseidon suggests to Zeus what he is going to do against the Phaeacians describing his threat into two steps. First he means to smite the Phaeacian boat as it approaches the coast of their land with an earthquake and then go to the second realization of his threat which is the encircling of their city by dropping on a huge mountain it.

Let us see the realization of his first part of his threat:

Od 13.159-13.164

"Now when the Poseidon the earth-shaker heard this he went to Scheria where the Phaeacians dwell, and there he waited. And she drew close to shore, the seafaring ship speeding swiftly on her way. Then near her came the Earth-shaker and turned her to stone and rooted her far beneath by a blow of the flat of his hand and then he was gone." 
After the realization of the first part of his threat the Phaeacians were very afraid. The reader can see what they wanted to do to avoid the imminent catastrophe which was the repetition by Poseidon of the crater's production. This is a view of the visitors prehistoric Greek in Iberia who interpreted the pre-existing crater there and region's seismicity at the period of their visit but in Homer is reflected upon the Phaeacians. The latter was possibly visible in the area. In the eyes of prehistoric visiting Greeks, the earthquake activity and the crater were connected directly with Poseidon acts, as they knew from the Aegean Sea, and applied in that area were connected as a severe godly thread against the local peoples. Let us read the next passage:

Od 13.178-13.184

"and now all this is being brought to pass. But now come, as I bid let us all obey. Cease to give convoy to mortals, when anyone comes to our city, and let us sacrifice to Poseidon twelve choice bulls, in hope that he may take pity, and not hide our city behind a huge encircling mountain".

Homer keeps repeating the term encircling mountain in a marine seismogenous region. This term requires explanation. In order to facilitate ourselves to understand Poseidon's very strange threat we should look in Fig.19. Did Poseidon in the seismogenous marine environment of Nisyros really produce a hole on it by throwing a huge rock or the preexisting crater that was interpreted by the Greeks as been done by Poseidon in the past? Certainly the second case is the correct one. In the light of this question we should see Poseidon's thread against the Phaeacians as a preexisting crater in a seismogenous environment. It has been interpreted as Poseidon's act of the past by the visiting prehistoric Greeks. Since the ongoing seismicity in the area was growing, the interpreters of the circular chasm as Poseidon's first act gave the impression to Phaeacians that he will repeat its act since he was the Earth-shaker. Their fear was based on their interpretation of a preexisting crater in the vicinity of their seismogenous land, as a result of Poseidon's act. Therefore the loss of their boat in the sea, due to an earthquake, increased the observing city's people anxiety of a possible repetition of a Poseidonian worst act since the god of the sea had sent his message. They frightened citizens of Scheria, who lived on or close to a nature made crater believed that Poseidon would throw a huge mountain at them as he did in the past producing the crater. This scenario of course is an impression of the prehistoric Greeks of the events in that region. Scheria of course can not be Corfu as Strabo suggested (Petridis, 1999). It is impossible for the Corfu people not have known the Trojan War when the other Ionian Islands knew it! Scheria, as Depos (1980), Petridis (1999) and Tziropoulou (2008) proposed, is Spain. It is impossible for Scheria to be in the Ionian Sea either since it is not the end of the known world. But Spain, in other words Scheria, was in the end of the known world for the Greeks as Homer and others described it.

\section{Conclusions}

Figure 11 illustrates Kambanakis' (1892) drawing following Plato’s Kritias.

Prior to Plato a nature made either of impactogenic or diapeirogenic origin concentric crater was once visible in Iberia's coast. Ancient authors before and after Plato mentioned it. Plato called it Atlantis and with the same name called a giant island and a horseshow basin. Plato built upon it in other words on pre-existing genuine myth his mathematical fantasies (Brambaugh, 1954). Kritias is the only dialogue which describes a genuine myth and a paramyth together whereas all other dialogues contain only paramyths. The genuine myth reflects the prehistoric and historic contact of the Greeks during the Tartessos and an Atlantic Ocean catastrophe which ruined the elder prehistoric Tartessos. The latter later was rebuilt and smoothly vanished due to Guadalquivir's accumulating sediments. 

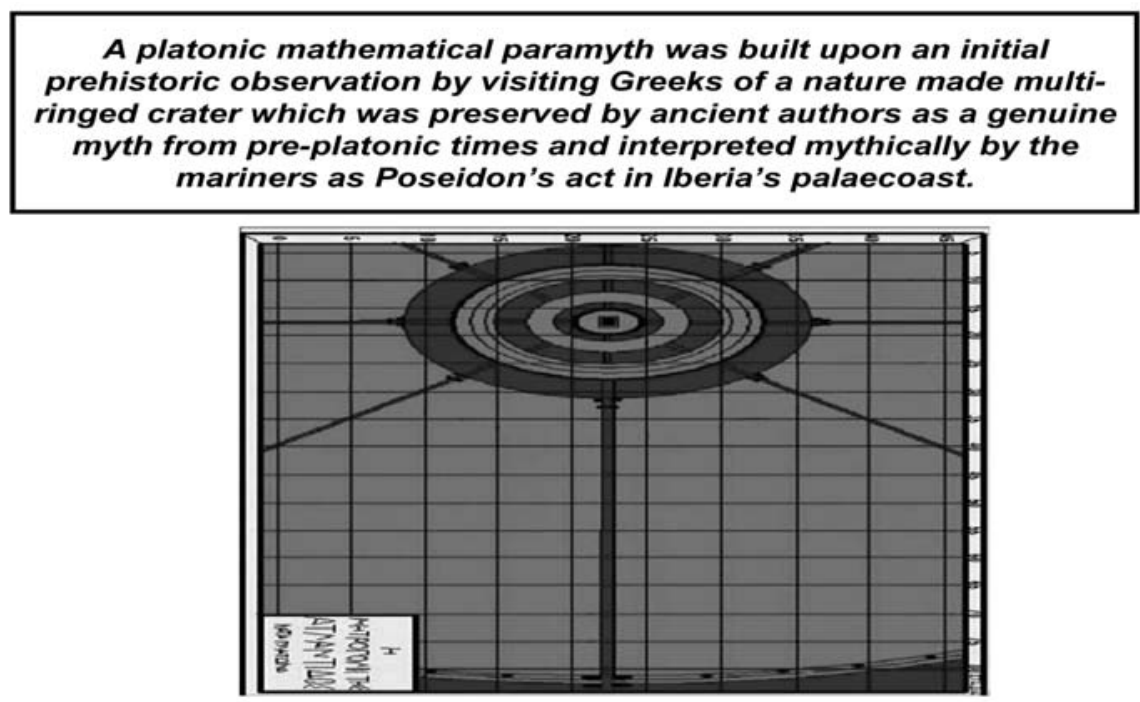

Fig. 11: Pactroclos Kambanakis (1892) was the fist in the modern period who produced Atlantis' picture on a grid. Today there are views on this scheme, shown above, based on differences of various philological elements.

\section{References}

Brumbaugh, R.S., 1954. Plato's mathematical imagination.'The mathematical passages in the dialogues and their interpretation". Indiana University Press, p.p.302.

Chalari, A., St. P. Papamarinopoulos, G. Papatheodorou and G.Ferentinos. The Achaeans' coming to Africa and the island of Pharos. Proceedings of the International Conference: The Atlantis Hypothesis: searching for a lost land, Athens 10-11 November 2008, Publisher: Heliotopos, Editor : Stavros Papamarinopoulos, (in print).

Depos,G. D., 1980. Odyssey “Historical and Geographic verification”, Editor Pallas, p.p. 213 (In Greek). Hellanicus.

Hesiod.

Homer.

Jordan, P., 2001. The Atlantis syndrome. Sutton publishing, p.p. 308.

Kabanakis, P., 1996. The communication, before the deluge, of the two worlds through Atlantis. A contribution to the study of communication of the prehistoric Greeks with America. First edition 1892, Second edition Ekate, Athens, (in Greek), 61 pp.

Matton, G., Jebrak M. \& Lee J. K. M., 2005. Resolving the Richat enigma: Doming and hydrothermal karstification above an alkaline complex. Geology, v.35, no 8, p.p. 665-668.

Montaxano, D. G. (www.antiguo.com).

Papamarinopoulos, St. P., Drivaliari, N. \& Coseyan, Ch., 2007. Red tears in the Atlantic Ocean. Proceedings of the International Conference: The Atlantis Hypothesis: searching for a lost land, Melos Island 11-13 July 2005, Publisher:Heliotopos, Editor: Stavros Papamarinopoulos, p.p. 539-571.

Philostratos (Flavios).

Pindar.

Plato. 
Petrides, S.P., 1999. Homer's Odyssey. “America's discovery by the ancient Greeks”, Editor D.Tassopoulos, p.p.446.

Resbergen Van, Pieter, Davy Depreiter, Bar Pannemans and Jean-Pierre Henriet., 2005. Sea floor expression of sediment extrusion and intrusion at the El Arraiche mud volcano field, Gulf of Cadiz. Journal of Geophysical Research, Vol.110, FO 2010, doi:10.1029?2004 JF00165, pages 3 from 13.

Rooij, D. Van, 2005. EOS, vol.86, no 49, p.p. 509-511.

Steisichoros.

Strabo.

Tziropoulou, A., 2007. Homer and the so called Homeric problems. Proceedings of the symposium "Homer Science and Technology", Ancient Olympia, (2006). Editor: St. A. Paipetis, p.p. 451-467.

Tsikalas, F., Papamarinopoulos, St. P. \& Shuvalov, V. V., 2007a. The origin of the multi-ringed concentric morphology of Atlantis capital and its relation to the Platonic scripts. Proceedings of the International Conference: The Atlantis Hypothesis: searching for a lost land, Melos Island, 11-13 July 2005, p.p. 203-211.

Tsikalas, F., Shuvalov, V. V. \& Papamarinopoulos, St. P., 2007b. A new geophysical interpretation of the Platonic multi-ringed concentric morphology of Atlantis capital based on numerical simulations. Proceedings of the International Conference: The Atlantis Hypothesis: searching for a lost land, Melos Island, 11-13 July 2005, p.p.193-202.

Weaver, P. P.E., 2005. Hotspot ecosystem research on the margins of European Seas. EOS, vol.86, no 24, p.p. 226-227. 